\title{
Has Mexico City's shift to commercially produced housing increased car ownership and car use?
}

\author{
Erick Guerra \\ University of Pennsylvania \\ erickg@design.upenn.edu
}

Abstract: Mexico City's principal form of housing production has shifted over the past two decades. More households now purchase houses in large commercially built housing developments than move into informal settlements. Looking at 1500 households in two suburban municipalities from a 2007 metropolitan travel survey, this study is the first to quantify differences in car ownership and car use across households in informal settlements and commercial housing developments. Accounting for income, proxies for wealth, household composition, and geography, households living in commercial housing developments are likely to own more cars and drive more than similar households in neighboring informal settlements. A test for residential self-selection finds no unobserved correlations across households that own cars and live in commercial housing developments, suggesting that the included controls do a good job of capturing the effects of residential self-selection or that the effects are limited. Something about the local land use and design of new commercial housing developments appears conducive to car ownership and use. Differences between the two settlement types, including more parking, wider streets, less-connected street-grids, and less accessible transit stops in commercial settlements, likely play a role.

\author{
Article history: \\ Received: December 28, 2013 \\ Received in revised form: \\ August 25, 2014 \\ Accepted: February 16, 2015 \\ Available online: May 29, 2015
}

\section{Introduction}

At 35,000 feet-a typical cruising altitude for a long-distance commercial flight-Los Héroes Tecámac looks a bit like an urban airport. Two long, thick, near-perpendicular, gray lines intersect like massive runways providing access from northwest to southeast and northeast to southwest. To the north are the unmistakable tan and green rectangles of agricultural land. To the east and west are the equally unmistakable curving black, gray, and tan specks and lines of informal urbanization that is so characteristic of Mexico City's peripheral neighborhoods and many like them around the world (Figure 1). Located almost 20 miles to the northeast of the historic center, Los Héroes, despite its somewhat unusual appearance from the air, is typical of contemporary housing developments in Mexico City on the ground. Over the past two decades, Mexico City's principal form of new housing production has shifted from an informal process, where households built their own properties generally in informal settlements on

Copyright 2015 Erick Guerra

http://dx.doi.org/10.5198/jtlu.2015.714

ISSN: 1938-7849| Licensed under the Creative Commons Attribution - Noncommercial License 3.0

The Journal of Transport and Land Use is the official journal of the World Society for Transport and Land Use (WSTLUR) and is published and sponsored by the University of Minnesota Center for Transportation Studies. This paper is also published with sponsorship from WSTLUR and the Institutes of Transportation Studies at the University of California, Davis, and the University of California, Berkeley. 
the periphery, to a formal process, where private developers acquire large peripheral lots, build new housing speculatively, and sell completed homes in massive developments to households that qualify for publicly subsidized mortgages (Monkkonen 2011a, 2011b, Pardo and Velasco Sánchez 2006). What look like thick gray lines from the air are rows of identical one-, two-, and three-story attached houses and condominiums along intersecting rectangular grids of arterial roads and linear culs-de-sac. Small parking spaces separate the building facades from the sidewalk and street.

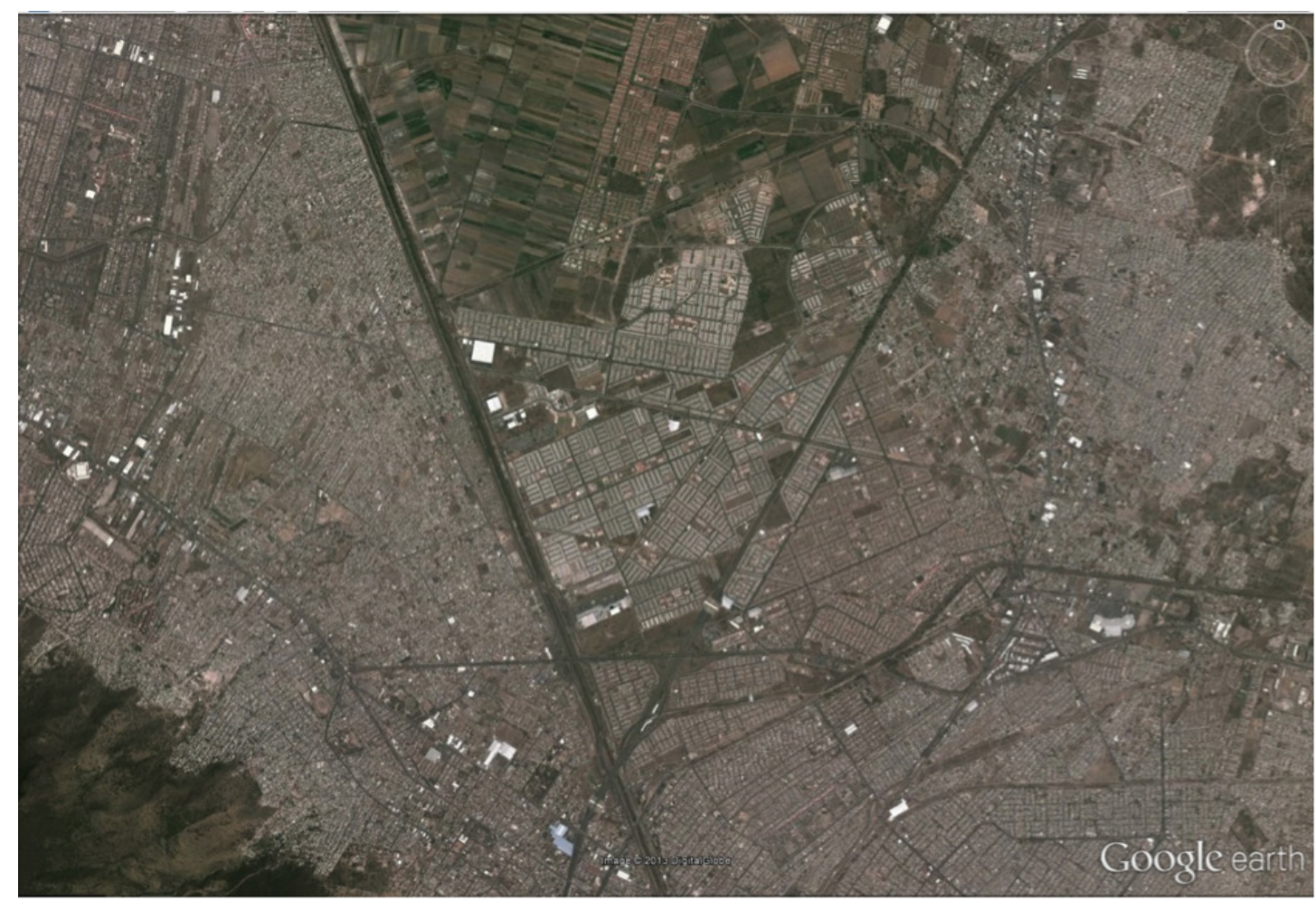

Figure 1: Aerial view of Los Héroes and surroundings in Ecatepec and Tecamac, State of Mexico (Google Earth 02-08-2013)

Changes in public policy, rather than demand, primarily drove this shift in housing production. Since Mexico's 1994 economic crisis and currency devaluation, the central government has pursued financial liberalization reforms including the reform of Infonavit, a national housing provident fund that requires private-sector employers to pay 5 percent of salaried workers' wages into the fund, which subsidizes loans for qualified low- to moderate- income workers to purchase newly built, privately produced homes (Monkkonen 2011a, Pardo and Velasco Sánchez 2006). Between 1995 and 2005, public agencies provided 75 percent of all housing loans by value - and even more by volume-in Mexico. Infonavit accounted for 81 percent of these publicly financed loans (Monkkonen 2011b). Smaller but similar housing funds for low-income workers with informal employment, government workers, and the stateowned oil company (Pemex) also contributed to the increase in commercial housing production. The legalization of sales of communally owned farmland, a simplification of housing construction regulations, and active political engagement with private developers also facilitated the rapid shift in housing production (Monkkonen 2011a).

In 1980, commercial developers produced just 15 percent of housing in the Mexico City metropolis (Dowall and Wilk 1989). By 2010, they produced the majority, particularly in fast-growing 
suburban municipalities like Tecamac. By the early 21st century, Mexico's largest commercial housing builders - Geo, Homex, Javer, Sadasi, and Urbi—were among the world's largest housing producers by volume. In 2010, Geo produced and sold more homes per year than the combination of D.R. Horton and the Pulte Group, the two largest housing producers by volume in the United States. All five of the above-mentioned Mexican companies would have made recent top-10 lists of the largest US housing producers (Hanley Wood LLC 2013, Nava 2011).

Over the same period as the shift in housing production occurred, car ownership and use have increased steadily. Between 2000 and 2010, the number of registered cars increased an average of 14 percent annually (INEGI 2013). Between 1994 and 2007, total vehicle kilometers traveled (VKT) on an average weekday increased from 24 to 32 million (Guerra 2014, INEGI 2007, 1994). Most of this growth has occurred in suburban municipalities outside of the Federal District of Mexico City where the shift in housing production has been so pronounced. In general, the new commercial housing developments are denser and closer to the city center than recently constructed housing in informal settlements (Monkkonen 2011c) but have less connected local street networks, and each housing unit comes with a single, exterior parking space. Although many residents convert parking into commercial retail spaces or residential additions over time, the default state has moved from one in which households expend land, energy, and resources to build a parking space to one in which they must expend time and energy to convert the parking to something else.

This paper provides the first empirical analysis of whether the shift in Mexico's housing policy is contributing to the rapid growth in car ownership and VKT in Mexico City. Are households that live in new commercial housing developments more likely to own and drive cars than similar households in nearby informal settlements? To what extent do differences in car ownership and use relate to local land use and design, or unobserved differences between households, such as a preference for driving and thus a preference to locate in new, more car-friendly neighborhoods?

Given the level of public involvement in housing production and the public desire to reduce emissions and congestion, the answers to these questions matter. If the increased driving of households in commercial housing developments is related to local land use or design, then the public sector has the opportunity to reduce car use by redesigning commercial housing developments and requiring new construction to follow design guidelines. If, by contrast, differences are primarily related to regional accessibility or varying household preferences, local design and land-use changes will have little to no influence on car use.

The answers also matter outside of Mexico City. There is a long and lively debate over whether and to what extent local land use and design influence travel behavior (Boarnet and Crane 2001, Brownstone 2008, Crane 2000, 1996, Ewing and Cervero 2010, Handy, Cao, and Mokhtarian 2005, Pickrell 1999). One point of particular contention is the extent to which residential self-selection influences the observed relationships with urban design and land use (for a discussion, see Mokhtarian and Cao 2008). In Mexico City, however, the recent and dramatic change in housing type may provide something akin to a natural experiment. The new housing product is uniform, giving households little chance to select amenities based on preferences. Furthermore, due to the housing subsidy, households are most likely choosing between living in a peripheral informal settlement or a peripheral commercial housing development based on loan eligibility rather than travel preferences. Since the new developments have the same levels of regional transit- and car-accessibility as the informal neighborhoods around them, differences in travel behavior that are related to the built environment stem from neighborhood rather than regional differences. If local land use and design influence travel in peripheral Mexico City, they also likely influence travel in the fast-growing peripheral neighborhoods of many other cities where population, suburbanization, and car ownership are increasing rapidly. 


\section{Research framework and methods}

\subsection{Study area and data}

This study focuses on two suburban municipalities: Ixtapaluca and Tecamac. Both grew rapidly between 1990 and 2010 - a period that coincides with the rapid shift from informal to formal housing production. Ixtapaluca, located about 30 kilometers east of Mexico City's historic center, grew at an average annual rate of 12 percent, adding 330,000 new residents between 1990 and 2010. At an average annual growth rate of 10 percent, Tecamac's population tripled from 120,000 to 360,000 residents over the same period. Figure 2 maps metropolitan population growth by municipality between the last two decennial censuses and shows the location of Ixtapaluca and Tecamac. Large-scale, high-density private commercial housing developments accounted for a substantial portion of the growth in both municipalities.

\begin{tabular}{|c|c|}
\hline & Federal District \\
\hline \multicolumn{2}{|c|}{ Study Area: } \\
\hline 1 & Tecamac \\
\hline 2 & Ixtapaluca \\
\hline \multicolumn{2}{|c|}{ Growth Rate: } \\
\hline$=$ & $-1.7 \%-0.0 \%$ \\
\hline & $0.0 \%-1.0 \%$ \\
\hline & $1.0 \%-3.0 \%$ \\
\hline & $3.0 \%-8.0 \%$ \\
\hline & $8.0 \%-16 \%$ \\
\hline
\end{tabular}

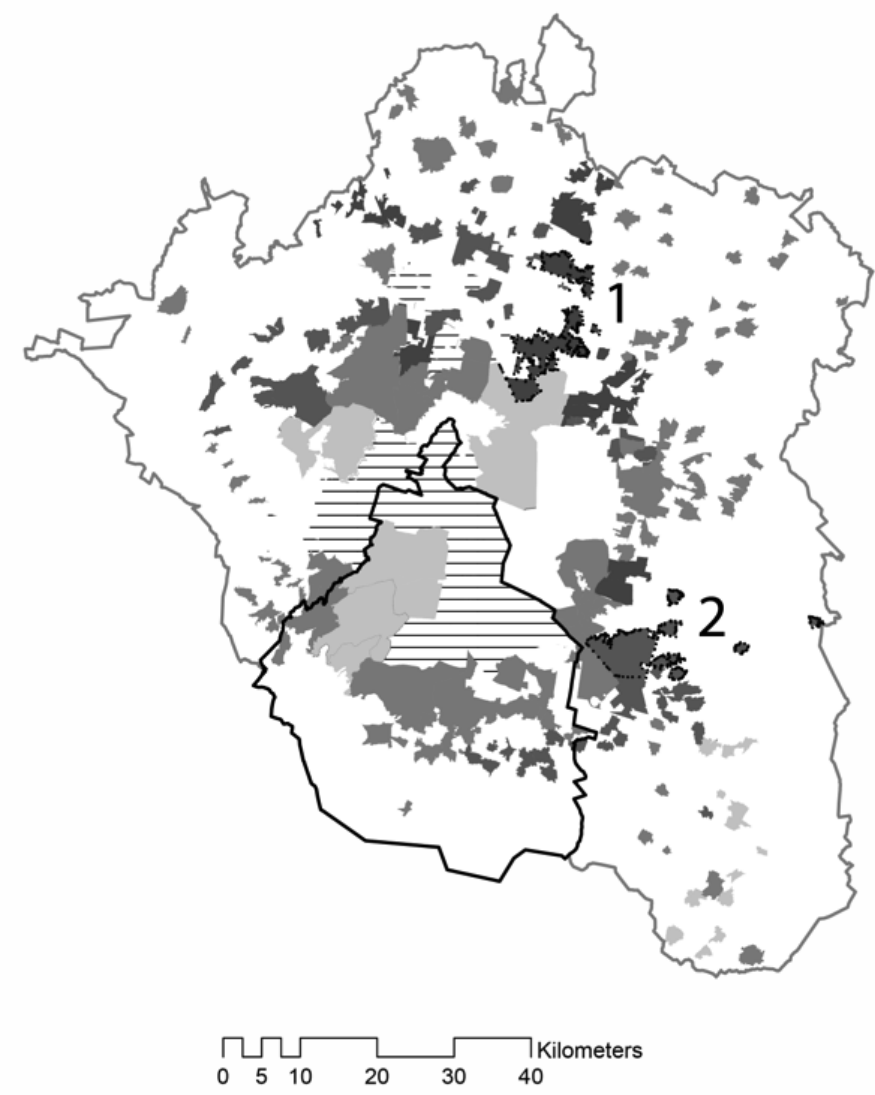

Figure 2: Mexico City's average annual population growth by municipality

Based on 2007 and 2008 satellite imagery from Google Earth, and first-hand knowledge of the new development sites, I drew geographic shapefiles around commercial housing developments and matched them with existing Census Tract shapefiles from the National Institute of Geography and Statistics (INEGI). Figure 3 shows the location of commercial housing developments in urbanized areas of Ixtapaluca and Tecamac. Each Census Tract then received a score ranging from 0 to 1 indicating the proportion of the tract that fell within a commercial housing development around the time of the 2007 metropolitan household travel survey (INEGI 2007). Figure 5 shows the distribution of the proportion 
of each Census Tract that overlapped the drawn shapefiles of commercial housing developments. Twothirds of Census Tracts contain either no commercial housing developments or only commercial housing developments. I then matched these data to household location, trip origin, and trip destination data from the 2007 metropolitan household travel survey.

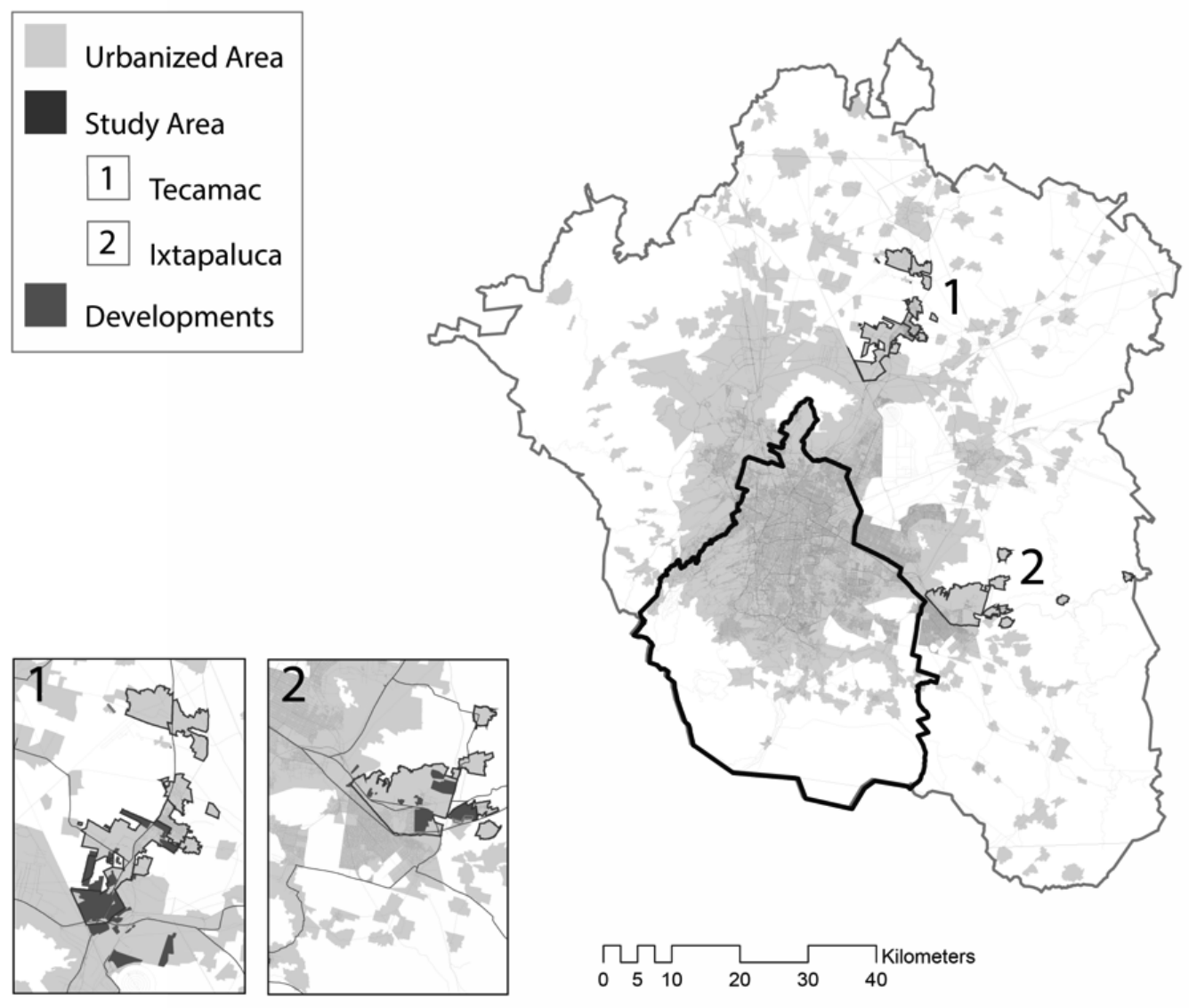

Figure 3: Location of large-scale commercial developments in Ixtapaluca and Tecamac

\subsection{Research hypotheses}

This study tests two overarching hypotheses about the relationship between living in a commercial housing development and owning and using cars.

H1: Households living in commercial housing developments are more likely to own and use cars than similar households in nearby informal settlements.

Commercial housing developments tend to have more parking, wider streets, and a more disconnected street grid than nearby informal housing developments. As a result, residents are more likely to own and use cars than those in informal settlements. Limiting the sample to two municipalities with similar levels of regional accessibility and including municipal-level fixed effects ensures that any differences found across households relates to local rather than regional differences.

Table 1 presents a list of control variables and their likely association with housing type and car ownership and use. Even within Ixtapaluca and Tecamac, there are likely some systematic differences between households in formal developments and those in informal ones. Many are also correlated with 
car ownership and use. For example, commercial housing residents are less likely to live in poverty since the new housing finance program has minimum income requirements. This is likely associated with higher car ownership and use. Computer ownership and home ownership are included as proxies for wealth, since income captures earnings, rather than total assets. Owning a computer may also correlate with lifestyle preferences that favor car ownership and use.

Table 1: Proposed control variables and expected correlation with whether

a household lives in a commercial housing development, car ownership, and car use

\begin{tabular}{|l|c|c|}
\hline Variable & $\begin{array}{c}\text { Commercial Housing } \\
\text { (Treatment Group) }\end{array}$ & $\begin{array}{c}\text { Car Ownership } \\
\text { and Use }\end{array}$ \\
\hline Car ownership & $(+)$ & NA \\
\hline Average daily VKT & $(+)$ & NA \\
\hline Household income & $(+)$ & $(+)$ \\
\hline Owns home & $(+)$ & $(+)$ \\
\hline Owns a computer & $(+)$ & $(+)$ \\
\hline Average age of household & $(-)$ & $(?)$ \\
\hline Presence of children & $(?)$ & $(+)$ \\
\hline Distance to downtown & $(?)$ & $(-)$ \\
\hline Distance to highway & $(?)$ & $(+)$ \\
\hline Distance to Metro & $(?)$ & $(-)$ \\
\hline Local population density & $(+)$ & $(-)$ \\
\hline
\end{tabular}

Source: 2007 Metropolitan Mexico City Household Travel Survey (INEGI

2007) and author's calculations

Written formally, the null hypothesis is $\boldsymbol{H O}: \boldsymbol{E}\left(\boldsymbol{Y}_{i} \mid \boldsymbol{D}_{i}, \boldsymbol{X}_{i}\right)=\boldsymbol{E}\left(\boldsymbol{Y}_{i} \mid \boldsymbol{X}_{i}\right)$

Where $\boldsymbol{E}$ is an expectation function;

$\boldsymbol{Y}$ is a variable indicating whether a household owns one or more cars and the number of VKT generated on the weekday of the household travel survey;

$D$ is a dummy variable that indicates whether a household lives in a commercial housing development;

$X$ is the vector of demographic and geographic control variables; and

$\boldsymbol{i}$ denotes a household.

H2: The relationship between commercial housing and car ownership and VKT is independent of unidentified differences between households in the two types of housing

Households tend to choose to live in neighborhoods that meet their transportation preferences. (For a discussion, see Cervero 2007, Chatman 2009, or Mokhtarian and Cao 2008.) As a result, households that favor transit often move into locations with good transit access, while households that wish to own a car tend to move to locations with available parking. To the extent that these preferences vary within the population and are independent of observed socioeconomic controls, they may bias estimates of the 
relationship between the built environment and travel behavior, particularly in cross-sectional studies. What may appear to be a causal relationship between living in dense neighborhoods and walking, for example, could be partially or even entirely caused by people with a strong preference for walking (and who would have walked in any environment) selecting to the densest, most walkable neighborhoods. In a review of 38 empirical studies, Cao, Mohktarian, and Handy (2009) found that this residential self-selection bias tends to lead to overestimates of the relationship between the built environment and travel, but that it only accounts for a portion of the correlation. To the extent that the built environment allows people to exercise preferences (if, for example, people who prefer to walk would not do so as much unless they could select into denser neighborhoods), the relationship is causal and not biased by residential self-selection. Given an undersupply or oversupply of specific neighborhood types, selfselection may even lead to underestimates of the influence of the built environment on travel (Chatman 2009, Levine 2006).

In Mexico City, the recent and dramatic change in housing type may provide something akin to a natural experiment in regard to residential self-selection. Instead of households choosing to live in a housing unit based on neighborhood preferences, the primary determinant of whether a household chooses to move into a new housing development is whether its members qualify for a subsidized home and are purchasing a new house. Since the commercial housing developments are all similar, there is little opportunity to select based on urban design or land-use preferences. Since the subsidy makes the housing cheaper relative to market alternatives, there is little incentive to purchase market-rate housing. By limiting the sample to households in two peripheral municipalities, the study design also limits potential selection bias to local rather than regional residential preferences, such as preference to live near downtown or near a Metro station. I therefore hypothesize that the effects of residential self-selection will be weak or unobservable, when conditioned on income and other socioeconomic attributes that correlate with living in a commercial housing development and owning and driving cars.

Mohtktarian and Cao (2008) and Cao, Mohtkarian, and Handy (2009) identify nine principal methods to identify and control for residential self-selection bias. A subset is applicable to this analysis, which relies on cross-sectional data and does not include a variable indicating residential preference. I use two such methods. The first is an instrument variable approach. For examples of applications to address residential self-selection bias, see Boarnet and Sarmiento (1998) or Vance and Hedel (2007). In theory, a good instrument is one that exerts influence on the outcome of interest (car ownership and use), but only through its influence on the treatment of interest (residence type) (Wooldridge 2010). In practice, finding good instruments is difficult (Angrist and Pischke 2008, Bound, Jaeger, and Baker 1995), and in LaLonde's (1986) landmark study of econometric methods, using them failed to replicate experimental results of the influence of worker training programs on employment-presumably a much more straightforward relationship than that between residential selection, the built environment, and travel behavior.

For instruments, I used whether households had members who worked in public-sector, administrative, or professional jobs. In theory, these job types make households more likely to qualify for Infonavit loans but no less likely to own a car or drive outside of their effect on wealth and income, which are included as controls. In practice, the instrument variable approach produced inconsistent parameter estimates depending on which job types were included as instruments and what other controls were included. I chose not to report the results.

The second approach in this study models car ownership and residential location simultaneously with a nested logit model, an approach used by Cervero (2007) and Salon (2009). Each household faces six different discrete choices: whether to live in a commercial housing development and whether to own zero, one, or two or more cars. If residential self-selection or other unobserved household attributes 
influence the correlation between living in a commercial development and owning a car, then nesting these choices and estimating a parameter for the nest should produce an estimate that ranges from zero to one, but is statistically different from one. The closer the estimate is to zero, the stronger the unobserved correlation between living in a commercial development and owning a car. For example, a nest value of 0.4 implies an unobserved correlation of 0.6 , and a value of 0.2 , a correlation of 0.8 . Cervero (2007) found a statistically significant unobserved correlation across households that live near rail transit and use it of almost 0.75 . If the nest value is either greater than or not statistically different from one, as in Salon's (2009) study of car ownership and residential location within New York, it indicates that the nesting parameter should not be included in the estimation.

\subsection{Descriptive statistics and model specification}

This section provides sources, means, and standard deviations for each of the independent and dependent variables modeled. It also describes the choice of expectation function used for car ownership and car use. As discussed in Section 2.1, the borders of commercial housing developments and Census Tracts do not match precisely (Figure 4). Most Census Tracts, however, have no commercial housing developments or only have commercial housing developments (Figure 5). Furthermore, since Census Tracts contain non-residential land uses, including roads, vacant land, and open space, the Census Tracts with a high percentage of commercial housing developments often have no other residential uses. Although somewhat of a simplification, I treat households residing in Census Tracts with 50 percent or more land comprised of commercial housing developments as residents of commercial housing developments. This may weaken the statistical relationships tested, but otherwise is unlikely to bias parameter estimates.
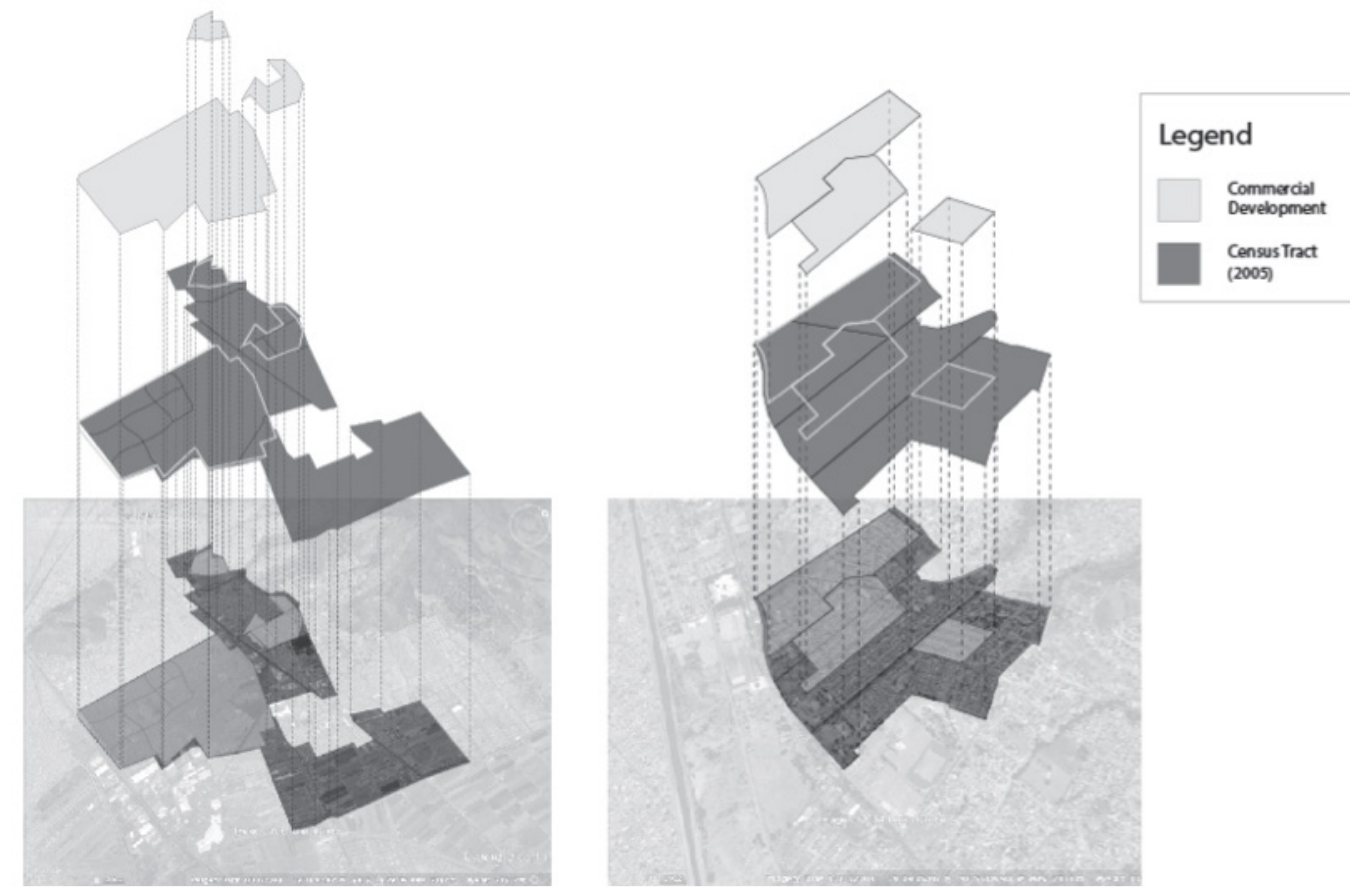

Figure 4: Matching and overlap of Census Tracts and commercial housing developments 


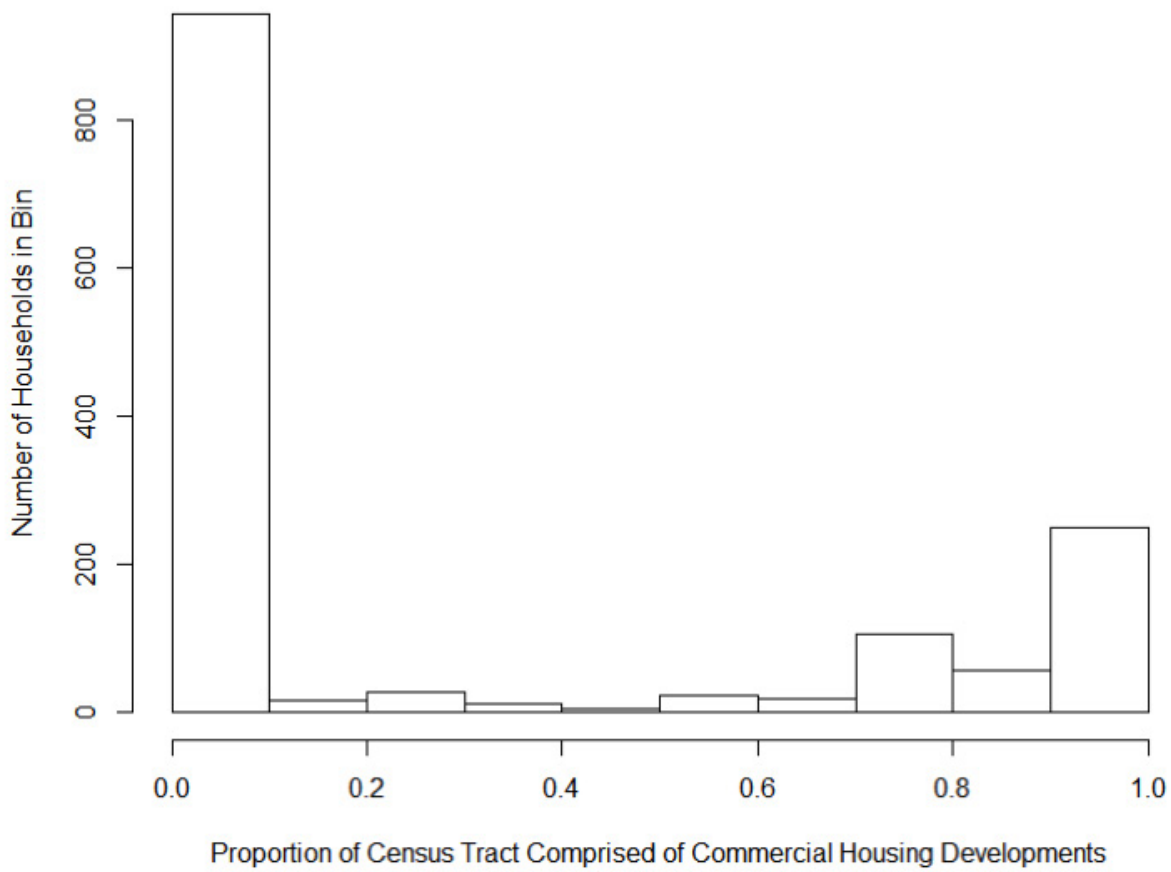

Figure 5: Histogram of households' residential location by the proportion of the Census Tract that is comprised of commercial housing developments

Table 2 presents the dependent and independent variables, based on whether households are assumed to live in traditional informal settlements or commercial housing developments.

As expected, residents of commercial housing developments tend to own more cars and drive more frequently than households in informal settlements. On average, households in commercial housing developments in Tecamac and Ixtapaluca own 56 percent more cars and generate 160 percent more weekday VKT than residents in traditional, informal housing developments. They also tend to have higher incomes, though only by 17 percent, and higher rates of home and computer ownership. The distribution of residents' income is also much tighter, presumably because households must meet minimum and maximum income requirements to qualify for a loan. In terms of geographic location, those in commercial housing developments tend to live in more densely populated neighborhoods that are marginally closer to Mexico City's historic center, the Metro system, and regional highways than those in traditional informal developments. This conforms to Monkkonen's (2011c) findings about commercial housing developments in 128 of Mexico's urban areas. A higher proportion of households in commercial developments were in Ixtapaluca than Tecamac, where several massive commercial housing developments have opened since 2007. 
Table 2: Sample means and standard deviations of independent and dependent variables by whether households reside in a Census Tract that is primarily comprised of commercial housing developments

\begin{tabular}{|c|c|c|c|c|}
\hline & \multicolumn{2}{|c|}{$\begin{array}{l}\text { Traditional Development } \\
\text { (Control Group) }\end{array}$} & \multicolumn{2}{|c|}{$\begin{array}{l}\text { Commercial Housing* } \\
\text { (Treatment Group) }\end{array}$} \\
\hline & Mean & SD & Mean & SD \\
\hline Average number of cars ${ }^{1}$ & 0.39 & 0.60 & 0.61 & 0.64 \\
\hline Has one or more cars ${ }^{1}$ & $34 \%$ & $48 \%$ & $54 \%$ & $50 \%$ \\
\hline Has two or more cars ${ }^{1}$ & $4 \%$ & $19 \%$ & $7 \%$ & $26 \%$ \\
\hline Average daily $\mathrm{VKT}^{2}$ & 6.0 & 20.1 & 15.6 & 33.2 \\
\hline Monthly income (in pesos) ${ }^{1}$ & $\$ 7431$ & $\$ 11,909$ & $\$ 8678$ & $\$ 6426$ \\
\hline People in household ${ }^{1}$ & 4.5 & 2.0 & 4.0 & 1.4 \\
\hline Household has children $^{1}$ & $56 \%$ & $50 \%$ & $62 \%$ & $49 \%$ \\
\hline Owns house $^{1}$ & $81 \%$ & $39 \%$ & $90 \%$ & $30 \%$ \\
\hline Average age of adults ${ }^{1}$ & 36.1 & 7.8 & 35.7 & 5.9 \\
\hline Has a computer $^{1}$ & $23 \%$ & $42 \%$ & $43 \%$ & $50 \%$ \\
\hline A member is college-educated ${ }^{1}$ & $45 \%$ & $77 \%$ & $70 \%$ & $80 \%$ \\
\hline A member works in public sector ${ }^{1}$ & $1 \%$ & $12 \%$ & $2 \%$ & $14 \%$ \\
\hline A member works in administration ${ }^{1}$ & $13 \%$ & $40 \%$ & $28 \%$ & $52 \%$ \\
\hline A member works in professional sector ${ }^{1}$ & $19 \%$ & $47 \%$ & $37 \%$ & $61 \%$ \\
\hline People per hectare in Census Tract ${ }^{3}$ & 107 & 74 & 204 & 100 \\
\hline Kilometers to Zocalo ${ }^{4}$ & 33.4 & 6.0 & 31.1 & 2.9 \\
\hline Accessibility score $^{2}$ & 61,026 & 32,767 & 69,541 & 31,312 \\
\hline Kilometers to highway ${ }^{4}$ & 1.2 & 0.9 & 0.9 & 0.6 \\
\hline Kilometers to Metro ${ }^{4}$ & 16.8 & 7.3 & 13.8 & 2.9 \\
\hline In Ixtapaluca ${ }^{1}$ & $54 \%$ & $50 \%$ & $68 \%$ & $47 \%$ \\
\hline Total Households (N) & 1070 & - & 456 & - \\
\hline
\end{tabular}

*indicates that a household lives in a Census Tract that is 50 percent or more comprised of commercial housing developments. Sources: 1) 2007 Metropolitan Mexico City Household Travel Survey (INEGI, 2007); 2) Travel survey and author calculations; 3) 2005 Census; and 4) Network-distance based calculation using household travel survey and road network shapefiles.

To estimate household car-ownership levels, I fit binomial logit, multinomial logit, and nested logit models. Only 5 percent of all households owned two or more cars. Sixty percent owned none. In the multinomial models, households choose between no cars, one car, or two-or-more cars. The nested logit model accounts for unobserved correlations between households that own a single car and those that own two or more. The nest, however, is not statistically different from one, and I opt to report the unordered multinomial logit model. To estimate VKT, I fit a left-censored Tobit model, which is commonly applied to joint discrete and continuous data including VKT. Three quarters of households did not have any members who drove on the survey day and thus produced no VKT. For a complete description of the model forms and estimation procedures, see Wooldridge (2010). Due to a long-tailed distribution, I log-transform the positive VKT data. This produces a better model fit and more homoscedastic residual plots. 


\section{New commercial housing development, car ownership, and car use}

After controlling for household income, age, composition, and location, the odds that the average household owns a single car are 61 percent higher in a commercial housing development than in a traditional neighborhood. The odds of owning two or more cars are 87 percent higher. Wealthier households that own their homes and a computer and have college-educated members are also significantly more likely to own cars. Neither the average age of adults in the household nor the number of people in the household is statistically correlated with a higher probability of car ownership. By contrast, households with one or more children are more likely to own a car. With the exception of the fixed effect for whether a household lives in Ixtapaluca, none of the geographic controls is statistically significantly associated with higher or lower car ownership. I opted to drop distance from the Metro, distance from Mexico City's historic center, and the accessibility score from the model since they were not significant and they are highly correlated with one another and the municipal fixed effect. This does not indicate that regional accessibility does not matter, but that there is insufficient variation within each municipality to estimate the correlation with car ownership.

Table 3: Multinomial logit model of car ownership in Tecamac and Ixtapaluca

\begin{tabular}{|c|c|c|c|c|}
\hline & Estimate & Std. Error & Odds-ratio & \\
\hline Commercial housing development: 1 cars & 0.48 & 0.15 & 1.61 & ** \\
\hline Commercial housing development: $2+$ cars & 0.62 & 0.32 & 1.87 & \\
\hline Log of income (in pesos): 1 car & 0.58 & 0.10 & 1.79 & *** \\
\hline Log of income (in pesos): $2+$ cars & 1.29 & 0.21 & 3.63 & *** \\
\hline Owns home: 1 car & 0.39 & 0.18 & 1.48 & * \\
\hline Owns home: $2+$ cars & 1.54 & 0.74 & 4.65 & * \\
\hline Has a computer: $1 \mathrm{car}$ & 0.80 & 0.14 & 2.22 & $* * *$ \\
\hline Has a computer: : $2+$ cars & 1.39 & 0.29 & 4.01 & *** \\
\hline College education: 1 car & 0.24 & 0.08 & 1.27 & $* *$ \\
\hline College education: $2+$ cars & 0.66 & 0.15 & 1.93 & *** \\
\hline Number of household members: 1 car & -0.03 & 0.04 & 0.97 & \\
\hline Number of household members: $2+$ cars & 0.04 & 0.09 & 1.05 & \\
\hline Average age of adults: $1 \mathrm{car}$ & 0.02 & 0.06 & 1.02 & \\
\hline Average age of adults: $2+$ cars & 0.07 & 0.18 & 1.07 & \\
\hline Average age of adults squared: $1 \mathrm{car}$ & 0.00 & 0.00 & 1.00 & \\
\hline Average age of adults squared: $2+$ cars & 0.00 & 0.00 & 1.00 & \\
\hline In Ixtapaluca: 1 car & -0.55 & 0.13 & 0.58 & *** \\
\hline In Ixtapaluca: $2+$ car & -0.71 & 0.28 & 0.49 & * \\
\hline Population per hectare: 1 car & 0.00 & 0.00 & 1.00 & \\
\hline Population per hectare: $2+$ cars & 0.00 & 0.00 & 1.00 & \\
\hline Constant: 1 car & -6.61 & 1.37 & & $* * *$ \\
\hline Constant: $2+$ cars & -18.42 & 3.74 & & *** \\
\hline
\end{tabular}

Significance codes: ${ }^{* * *} 0.001,{ }^{* *} 0.01,{ }^{*} 0.05, .0 .1$, McFadden R2: $0.128, \mathrm{~N}=1478$

Due to non-linearity, logit model coefficients and odds ratios only provide behavioral information about a theoretical average household. Table 4 shows the car ownership levels that the model predicts assuming that either no households or all households live in a commercial housing development. If no households live in commercial housing developments, the model predicts that 38 percent of households would own 
one or more cars, compared to 48 percent if all households lived in commercial housing developments.

Table 4: Predicted car ownership rates based on no, some, or all households living in commercial housing developments

\begin{tabular}{|l|r|r|r|}
\hline & \multicolumn{1}{|c|}{ No cars } & \multicolumn{1}{c|}{ One car } & \multicolumn{1}{c|}{ Two-plus cars } \\
\hline No commercial housing & $61.9 \%$ & $33.6 \%$ & $4.4 \%$ \\
\hline $\begin{array}{l}\text { Existing conditions (31\% } \\
\text { commercial housing) }\end{array}$ & $58.6 \%$ & $36.3 \%$ & $5.0 \%$ \\
\hline All commercial housing & $51.7 \%$ & $42.2 \%$ & $6.0 \%$ \\
\hline
\end{tabular}

Living in a commercial housing development also correlates with producing statistically significantly more VKT per weekday than living in a traditional, informal neighborhood (Table 5). On average, a household in a commercial development generates four times more latent VKT (the exponent of 1.408 equals 4.088) than a similar household in an informal settlement. The Tobit regression, however, primarily predicts negative values since two-thirds of households produced no VKT on the survey day. This coefficient must therefore be interpreted with caution. At the mean predicted latent VKT of -2.479 , the model does not expect a change in actual VKT from a household moving from an informal settlement to a commercial housing development, since latent VKT would still be negative. An ordinary least squares regression on the subset of households with VKT above zero produces a weaker, though still statistically significant result: Households in commercial developments generate 80 percent more VKT (with a T-value of 4.2) than households in traditional neighborhoods. The Tobit model also finds strong positive correlations between car use and households' income, educational attainment, and computer ownership. Higher population densities and residence in Ixtapaluca are associated with fewer weekday VKT.

Table 5: Type I Tobit model of log of households' weekday VKT in Tecamac and Ixtapaluca

\begin{tabular}{|l|r|r|r|}
\hline & \multicolumn{1}{|c|}{ Estimate } & \multicolumn{1}{|c|}{ Std. Error } & \\
\hline Commercial housing development & 1.408 & 0.340 & $* * *$ \\
\hline Log of monthly income (in pesos) & 1.310 & 0.215 & $* * *$ \\
\hline Owns home & 0.047 & 0.402 & \\
\hline Has a computer & 1.165 & 0.310 & $* * *$ \\
\hline College education & 0.898 & 0.174 & $* * *$ \\
\hline People in household & 0.023 & 0.089 & \\
\hline Household has children & 0.769 & 0.315 & $* *$ \\
\hline Average age of adults & -0.187 & 0.144 & \\
\hline Average age squared & 0.002 & 0.002 & \\
\hline In Ixtapaluca & -1.088 & 0.288 & $* * *$ \\
\hline People per hectare in Census Tract & -0.003 & 0.002 & $*$ \\
\hline Constant & -11.435 & 3.075 & $* *$ \\
\hline
\end{tabular}

Significance codes: ${ }^{* * *} 0.001,{ }^{* *} 0.01,{ }^{*} 0.05, .0 .1$, McFadden R2: 0.063

To demonstrate the stability of the estimated average effect of living in a commercial housing development on car ownership and VKT and the relationship to the control variables, Table 6 provides coefficient estimates from four additional multinomial logit and Tobit models with fewer controls, as well as the coefficients with full controls as presented in Tables 4 and 5. Without any controls, households in commercial housing developments have more than twice the odds of owning one or more cars than those in traditional informal neighborhoods. Introducing controls for income, wealth, household com- 
position, and geographic features, the odds drop to 50 percent to 60 percent higher. Similarly, predicted VKT drops when controlling for household income, wealth, and demographics. The correlation, however, strengthens when geographic variables are introduced. Commercial housing developments tend to have higher population densities, which are associated with fewer weekday VKT per household. The association between living in a commercial housing development and owning two or more cars is not always statistically different from zero with controls included, which is likely due to the small sample of households with two-or-more cars. In none of the models is it statistically different from the relationship to owning one car.

Table 6: Relationship between living in commercial housing development and household car ownership and weekday VKT

\begin{tabular}{|c|c|c|c|c|c|}
\hline \multicolumn{2}{|c|}{ Multinomial logit model } & Tobit model & \multicolumn{3}{|c|}{ Controls } \\
\hline One car & Two-plus cars & Log of VKT & Income and wealth & Household composition & Geography \\
\hline $0.73^{* * *}$ & $0.89^{* * *}$ & $1.67^{* * *}$ & $(\mathrm{No})$ & $(\mathrm{No})$ & $(\mathrm{No})$ \\
\hline $0.44^{* *}$ & 0.40 & $0.96^{* * *}$ & $(\mathrm{Yes})$ & $(\mathrm{No})$ & $(\mathrm{No})$ \\
\hline $0.40^{* *}$ & 0.37 & $0.96^{* * *}$ & $(\mathrm{Yes})$ & $(\mathrm{Yes})$ & $(\mathrm{No})$ \\
\hline $0.48^{* *}$ & 0.62. & $1.41^{* * *}$ & $(\mathrm{Yes})$ & $($ Yes $)$ & $($ Yes $)$ \\
\hline
\end{tabular}

Significance codes: ${ }^{* * *} 0.001,{ }^{* *} 0.01,{ }^{*} 0.05, .0 .1$

\subsection{Testing for residential self-selection}

The nested logit model of residential location and car ownership produces generally similar estimates of the relationship between socioeconomic control variables and car ownership (Table 7). It also indicates that a number of the control variables are indeed associated with whether households live in commercial housing developments. For example, smaller, wealthier households with computers are more likely to live in commercial housing developments. As expected, households with members who work in professional or administrative jobs are more likely to live in commercial housing developments. Government employment is not statistically correlated, likely because government employees qualify for a separate fund, the Housing Fund of the Institute of Social Security of State Workers. The model includes two nest parameters, one for car ownership and one for the combination of car ownership and residence in a commercial housing development. The car-ownership nest of 0.83 indicates an unobserved 17 percent correlation across households that own cars. However, the value is not statistically different from one. The nest for car ownership and commercial residence is greater than one, which indicates that the choices are not correlated and should not be nested. Again, however, the value is not statistically different from one. Residential self-selection does not appear to play a significant role in influencing the car-ownership parameter. This supports the hypothesis that the rapid change in housing production has limited the effects of residential self-selection. The rich set of socioeconomic control variables may also do a good job of capturing the effects of residential self-selection as found in studies by Brownstone and Golob (2009) and Bhat and Guo (2007). 
Table 7: Nested logit model of joint decision of how many cars to own and whether to live in a commercial housing development

\begin{tabular}{|c|c|c|c|c|}
\hline & Estimate & Std. Error & Odds-ratio & \\
\hline \multicolumn{5}{|l|}{ Car ownership } \\
\hline Log of monthly income: 1 car & 0.587 & 0.093 & 1.799 & *** \\
\hline Log of monthly income: $2+$ cars & 1.223 & 0.235 & 3.397 & *** \\
\hline Owns home: 1 car & 0.438 & 0.177 & 1.550 & * \\
\hline Owns home: $2+$ cars & 1.622 & 0.856 & 5.064 & \\
\hline Has a computer: $1 \mathrm{car}$ & 0.794 & 0.140 & 2.213 & $* * *$ \\
\hline Has a computer: $2+$ cars & 1.353 & 0.331 & 3.870 & *** \\
\hline College education: 1 car & 0.234 & 0.083 & 1.264 & ** \\
\hline College education: $2+$ cars & 0.633 & 0.172 & 1.884 & *** \\
\hline People in household: 1 car & -0.030 & 0.038 & 0.970 & \\
\hline People in household: $2+$ cars & 0.019 & 0.099 & 1.019 & \\
\hline Average age of adults: $1 \mathrm{car}$ & 0.018 & 0.066 & 1.018 & \\
\hline Average age of adults: $2+$ cars & 0.057 & 0.174 & 1.058 & \\
\hline Average age squared: $1 \mathrm{car}$ & 0.000 & 0.001 & 1.000 & \\
\hline Average age squared: $2+$ cars & 0.000 & 0.002 & 1.000 & \\
\hline In Ixtapaluca: 1 car & -0.605 & 0.130 & 0.546 & *** \\
\hline In Ixtapaluca: $2+$ cars & -0.779 & 0.298 & 0.459 & ** \\
\hline Population per hectare: 1 car & 0.001 & 0.001 & 1.001 & \\
\hline Population per hectare: $2+$ cars & -0.001 & 0.002 & 0.999 & \\
\hline \multicolumn{5}{|l|}{ Lives in commercial housing development } \\
\hline Log of monthly income & 0.178 & 0.103 & 1.195 & . \\
\hline Has a computer & 0.421 & 0.136 & 1.524 & ** \\
\hline College education & 0.007 & 0.083 & 1.007 & \\
\hline People in household & -0.322 & 0.051 & 0.725 & $* * *$ \\
\hline Average age of adults & 0.340 & 0.075 & 1.405 & *** \\
\hline Average age squared & -0.005 & 0.001 & 0.995 & $* * *$ \\
\hline In Ixtapaluca & 0.566 & 0.136 & 1.761 & *** \\
\hline Professional job & 0.562 & 0.164 & 1.755 & *** \\
\hline Administrative job & 0.770 & 0.164 & 2.161 & *** \\
\hline Public sector job & 0.050 & 0.424 & 1.051 & \\
\hline \multicolumn{5}{|l|}{ Nests } \\
\hline Car ownership and commercial development & 1.246 & 0.662 & & \\
\hline Car ownership & 0.831 & 0.240 & & \\
\hline
\end{tabular}

Significance codes: ${ }^{* * *} 0.001,{ }^{* *} 0.01,{ }^{*} 0.05, .0 .1$, McFadden R2: $0.118, \mathrm{~N}=1478$, Constants not reported to conserve space

\section{Discussion}

There is a clear and statistically significant positive correlation between living in commercial housing developments and owning and using cars in Tecamac and Ixtapaluca, two suburban municipalities of Mexico City. Given the rapid shift in housing production from an informal process to a formal one, whether, how, and to what extent this relationship is causal is of great policy concern. Congestion, in 
particular, has large social and economic costs; the average one-way commute lasted 72 minutes for residents of the two municipalities in 2007 (INEGI 2007). Furthermore, due to the federal role in financing mortgages for commercial housing developments, the central government has unusually strong control over the design, location, and regulation of future commercial housing developments like those in Ixtapaluca and Tecamac. While this study cannot definitively quantify a causal relationship, it does suggest that one exists. This section discusses the evidence for the positive relationship being causal and then considers why commercial housing might produce higher rates of car ownership and use.

There are two principal reasons that living in commercial housing developments is likely to correlate with higher car ownership and use. Either the developments attract households with a stronger preference for driving and car ownership or there is something about the design and location of the developments that is conducive to driving and car ownership. The descriptive statistics and regression results strongly indicate that commercial housing developments attract wealthier households with observed preferences for driving. Including income, home ownership, and computer ownership in the statistical models reduces the average correlation between residing in a commercial housing development and car ownership and weekday driving by around 40 percent. There may also be unobserved variables that correlate with car ownership and driving as well as living in a commercial housing development, and bias estimates of the relationship between commercial housing development and car ownership and driving. Possibilities include personal preference, job location, and social status above and beyond what might be captured by income, home ownership, educational attainment, and computer ownership. However, the results from the nested logit model suggest that this is not the case. Furthermore, the strength of the observed relationship and the rapid and exogenous shift in housing production-since selection into a commercial development is largely determined by whether a household qualifies for a loan, rather than residential preference-both suggest that there is something about the commercial housing developments that encourages higher rates of car ownership and use.

Since the analysis draws data from two similar suburban municipalities and includes a fixed effect for one of them, any of the observed relationship between the physical form of commercial housing developments and car ownership and use is related to local features, like design or local transit access, rather than regional ones, like accessibility to job centers. There are also likely to be differences related to regional accessibility, as found in a study of car use in metropolitan Mexico City (Guerra 2014), but this study would not capture them.

Unfortunately, the analysis cannot provide insight into which aspects of commercial housing developments correlate most strongly with higher car ownership or use. There is simply not enough variation in the design and land use of commercial housing developments. Furthermore, this shortcoming is common in studies of the relationship between the built environment and travel, either because a variable like neighborhood population density serves as a proxy (intentional or not) for other measures (see for example Brownstone and Golob 2009), or the measure of the built environment is a qualitative dummy variable for a neighborhood type (see for example Handy, Cao, and Mokhtarian 2005).

Given the evidence that there may be a causal link between the local features of commercial housing developments and car ownership and car use, it is worth considering how peripheral commercial housing developments differ from nearby informal neighborhoods. Both tend to contain small, fairly uniform, cement housing units on small lots. Both are primarily constructed on former communal farmland. In Tecamac and Ixtapula, commercial developments tend to be more densely populated. Perhaps the most apparent difference is in how these neighborhoods develop over time. Informal neighborhoods grow organically over time, with residents and entrepreneurs building housing units and shops to suit their needs. By contrast, residents move into fully constructed single-use residential neighborhoods in commercial housing developments, although residents often convert units or parking spaces into 
shops over time. With limited access points, furthermore, informal transit, which serves around half of all metropolitan trips (INEGI 2007), is generally less well-integrated into commercial housing developments than informal neighborhoods. Geo built the 11,000-unit Villas de Santa Barbara in Ixtapaluca with just three access points (Peralta and Hofer 2006). Rather than providing stations at the center of a 10,000-unit development, informal transit operators will generally pick up and drop off passengers at the edges.

Ample parking likely plays a particularly important role. Roadways are wider than in informal settlements allowing for more on-street parking and each unit has an off-street parking space. Many households would not voluntarily choose to expend time, land, and money to create a parking space from scratch —indeed many take the time and effort to convert parking into some other use- but the default suburban housing product in Mexico City now comes with parking, when previously it did not. If indeed, "[m]inimum parking requirements are truly a great planning disaster-perhaps the greatest of all time [in the United States] (Shoup 2005, p. 218)," the potential costs in rapidly motorizing metropolitan areas like Mexico City are alarming. More than three in four children born today will live in a city in a developing country (United Nations Population Division 2007). Most will live in newly forming neighborhoods in rapidly motorizing suburban locations like Tecamac and Ixtapaluca. The parking policies adopted by these metropolitan areas will have tremendous economic, social, and environmental costs, both locally and globally.

\section{Conclusion}

This paper examined the correlation between living in a commercial housing development and owning and driving a car across 1500 households in two suburban municipalities in Mexico City. Accounting for income, proxies for wealth, household composition, and geography, residents of an average household living in commercial housing developments are 61 percent more likely to own a car and 87 percent more likely to own two or more cars than those of a similar household in a neighboring informal settlement. They also generate significantly more private vehicle travel on an average weekday. While some of the differences in car ownership and use may relate to unobserved household preferences, the rapid shift in housing production and the results of a nested logit model of car ownership and residential location suggest that something about the new commercial housing developments is more conducive to car ownership and use. Since the sample only includes households from two similar suburban municipalities and the models include regional controls, the observed statistical correlations likely stem from differences in local land use and design. The shift in housing policy has almost certainly increased car ownership and use.

In the wake of the Great Recession, this policy is starting to change. Hundreds of thousands of new homes sit vacant throughout Mexico. Not only have new homes not been purchased, each year Infonavit and other lenders foreclose on tens of thousands of homes (Juarez 2013). Homes in the most peripheral new developments have been particularly vulnerable. Housing fund administrators have responded by cutting lending and reorienting the fund's portfolio to the renovation and resale of existing properties. Meanwhile, the national homebuilders have hit rock bottom. Geo and Urbi, both publicly traded, failed to report second quarter earnings in 2013 and were suspended from trading on the Mexican stock exchange (Purnell 2013). Days earlier, Homex, which reported earnings, experienced the steepest drop in value of any highly traded company on the Bloomberg World Index (Levin 2013). Workers' unions are demanding better, larger housing in more central locations, greater leniency for unemployed workers with mortgages, and expanded access to credit for poorer households. The new administration of President Peña Nieto has made expanding access to credit and reorienting lending to support vertical construction in more central locations public-policy priorities (La Crónica de Hoy 2013). While it is 
unclear precisely how Infonavit or housing production will respond to the growing and often conflicting interests and priorities of private homebuilders, workers, and the public sector, it is clear that they are changing. This study finds that, from the perspective of limiting the growth in car ownership and use, the local design and land use of commercial housing developments matter. In addition to promoting more centralized, vertical development, policymakers should pay more attention to designing and retrofitting peripheral commercial housing developments in ways that do less to encourage driving. Theory, previous findings, and differences with informal settlements suggest that fewer parking spaces, more connected street grids, and better local transit access would help.

\section{References}

Angrist, J. D., and J. S. Pischke. 2008. Mostly Harmless Econometrics: An Empiricist's Companion, 1st ed. Princeton, NJ: Princeton University Press.

Bhat, C. R., and J. Y. Guo. 2007. A comprehensive analysis of built environment characteristics on household residential choice and auto ownership levels. Transportation Research Part B: Methodological 41: 506-526. doi:10.1016/j.trb.2005.12.005

Boarnet, M., and R. Crane. 2001. The influence of land use on travel behavior: Specification and estimation strategies. Transportation Research Part A: Policy and Practice 35: 823-845. doi:10.1016/ S0965-8564(00)00019-7

Boarnet, M., and S. Sarmiento. 1998. Can land-use policy really affect travel behavior? A study of the link between non-work travel and land-use characteristics. Urban Studies 35: 1155-1169. doi:10.1080/0042098984538

Bound, J., D. A. Jaeger, and R. M. Baker. 1995. Problems with instrumental variables estimation when the correlation between the instruments and the endogenous explanatory variable is weak. Journal of the American Statistical Association 90: 443-450. doi:10.1080/01621459.1995.10476536

Brownstone, D. 2008. Key Relationships Between the Built Environment and VMT (Special Report No. 298), Driving and the Built Environment: The Effects of Compact Development on Motorized Travel, Energy Use, and CO2 Emissions. Washington, DC: Transportation Research Board.

Brownstone, D., and T. F. Golob. 2009. The impact of residential density on vehicle usage and energy consumption. Journal of Urban Economics 65: 91-98. doi:10.1016/j.jue.2008.09.002

Cao, X., P. Mokhtarian, and S. Handy. 2009. Examining the impacts of residential self-selection on travel behavior: A focus on empirical findings. Transport Reviews 29: 359-395. doi:10.1080/01441640802539195

Cervero, R. 2007. Transit-oriented development's ridership bonus: A product of self-selection and public policies. Environment and Planning A 39: 2068-2085.

Chatman, D. 2009. Residential choice, the built environment, and nonwork travel: Evidence using new data and methods. Environment and Planning A 41: 1072-1089.

Crane, R. 1996. On form versus function: Will the new urbanism reduce traffic, or increase it? Journal of Planning Education and Research 15: 117 -126. doi:10.1177/0739456X9601500204

Crane, R. 2000. The influence of urban form on travel: An interpretive review. Journal of Planning Literature 15: 3-23. doi:10.1177/08854120022092890

Dowall, D. E., and D. Wilk. 1989. Population growth, land development, and housing in Mexico City (Working Paper No. 502). University of California at Berkeley, Institute of Urban and Regional Development, Berkeley.

Ewing, R., and R. Cervero. 2010. Travel and the built environment: A meta-analysis. Journal of the American Planning Association 76: 265-294. doi:10.1080/01944361003766766

Guerra, E. 2014. The built environment and car use in Mexico City is the relationship changing over 
time? Journal of Planning Education and Research 34: 394-408. doi:10.1177/0739456X14545170

Handy, S., X. Cao, and P. Mokhtarian. 2005. Correlation or causality between the built environment and travel behavior? Evidence from Northern California. Transportation Research Part D: Transport and Environment 10: 427-444. doi:10.1016/j.trd.2005.05.002

Hanley Wood, LLC. 2013. 2010 Builder 100 [WWW Document]. URL: http://www.builderonline. com/builder100/2010.aspx.

INEGI. 1994. Encuesta Origen-Destino de los Viajes de los Residentes de la Zona Metropolitana del Valle de México 1994. Mexico City: Instituto Nacional de Estadística, Geografía e Informática.

INEGI. 2007. Encuesta Origen-Destino de los Viajes de los Residentes de la Zona Metropolitana del Valle de México 2007. Mexico City: Instituto Nacional de Estadística, Geografía e Informática.

INEGI. 2013. Instituto Nacional de Estadística y Geografía [WWW Document]. URL: http://www. inegi.org.mx/.

Juarez, E. 2013. Sedatu busca atacar abandono de vivienda. El Economista.

La Crónica de Hoy. 2013. Ordena Peña Nieto Revisar Requisitos Para Otorgar Créditos de Vivienda. Mexico City: La Crónica de Hoy.

LaLonde, R. J. 1986. Evaluating the econometric evaluations of training programs with experimental data. The American Economic Review 76(4): 604-620.

Levine, J. 2006. Zoned Out: Regulation, Markets, and Choices in Transportation and Metropolitan Land Use. Washington, DC: RFF Press.

Levin, J. 2013. Homex posts world's worst selloff on Mexican homebuilder's loss. Bloomberg Business.

Mokhtarian, P., and X. Cao. 2008. Examining the impacts of residential self-selection on travel behavior: A focus on methodologies. Transportation Research Part B: Methodological 42: 204-228. doi:10.1016/j.trb.2007.07.006

Monkkonen, P. 2011a. The housing transition in Mexico expanding access to housing finance. Urban Affairs Review 47: 672-695. doi:10.1177/1078087411400381

Monkkonen, P. 2011b. Housing finance reform and increasing socioeconomic segregation in Mexico. International Journal of Urban and Regional Research 36: 757-772. doi:10.1111/j.14682427.2011.01085.x

Monkkonen, P. 2011c. Do Mexican cities sprawl? Housing-finance reform and changing patterns of urban growth. Urban Geography 32: 406-423. doi:10.2747/0272-3638.32.3.406

Nava, R. 2011. Geo es líder en venta de casas con crédito Infonavit [WWW Document]. BMV Traders. URL: http://bmvtraders.com/2011/01/geo-es-lider-en-venta-de-casas-con-credito-infonavit/.

Pardo, M. del C., and E. Velasco Sánchez. 2006. El Proceso de Modernización en el Infonavit 2001-2006: Estrategia, redes y liderazgo. Mexico, DF: Colegio de México.

Peralta, B. G., and A. Hofer. 2006. Housing for the working class on the periphery of Mexico City: A new version of gated communities. Social Justice 33: 129-141.

Pickrell, D. 1999. Transportation and land use. In Transportation Economics and Policy Handbook, edited by J. Gomez-Ibanez, W. B. Tye, and C. Winston. Washington, DC: Brookings Institution Press.

Purnell, N. 2013. Homex jumps after government pledges support: Mexico City mover. Bloomberg Business.

Salon, D. 2009. Neighborhoods, cars, and commuting in New York City: A discrete choice approach. Transportation Research Part A: Policy and Practice 43: 180-196. doi:10.1016/j.tra.2008.10.002

Shoup, D. 2005. The High Cost of Free Parking, illustrated edition. Chicago, IL: American Planning Association.

United Nations Population Division. 2007. World Urbanization Prospects: The 2007 Revision Population Database [WWW Document]. URL: http://esa.un.org/unup/ (accessed 8.25.11). 
Vance, C., and R. Hedel. 2007. The impact of urban form on automobile travel: Disentangling causation from correlation. Transportation 34: 575-588. doi:10.1007/s11116-007-9128-6

Wooldridge, J. M. 2010. Econometric Analysis of Cross Section and Panel Data, second edition. Cambridge, MA: The MIT Press. 